Avaing Tera
Ling Tera, $6(1), 2019,41-50$

\title{
Speaking materials for conversation class at Islamic senior high school
}

\author{
Mujawazah Mujawazah $^{1 *}$, Agus Widyantoro ${ }^{2}$ \\ ${ }^{1}$ Institut Ilmu Al Qur'an An Nur Yogyakarta, Komplek Pondok Pesantren An Nur Ngrukem \\ Sewon Bantul Yogyakarta 55185, Indonesia \\ ${ }^{2}$ Department of English Education, Program Pascasarjana, Universitas Negeri Yogyakarta \\ Jalan Colombo No. 1, Yogyakarta, 55281, Indonesia \\ *Corresponding author. Email jaymifta2408@gmail.com \\ Received: 13 March 2018; Revision: 15 April 2019; Accepted: 19 June 2019
}

\begin{abstract}
This research study aimed to develop English speaking materials to support the learning process in Conversation class of the tenth-graders at Madrasah Aliyah (Islamic senior high school) Al Ma'had An Nur, Bantul. This research was a research and development study. The development was carried out through several steps, namely the needs analysis, a course grid design, product development, product validation, product revisions, try-outs, and final product development. The research had two results. First, it produced a set of speaking materials in the form of printed books. Second, the findings showed that the materials were appropriate to be applied in the Conversation class of the tenth-graders at Madrasah Aliyah Al Ma'had An Nur, Bantul considering the result of the materials evaluation by experts and students' try-outs. They scored 3.59 and 3.32 for the mean score of the scale 1 to 4 and were categorized as "Very Good".
\end{abstract}

Keywords: develop, speaking, learning materials, conversation class

How to Cite: Mujawazah, M., \& Widyantoro, A. (2019). Speaking materials for conversation class at Islamic senior high school. LingTera, 6(1), 41-50. doi:https://doi.org/10.21831/lt.v6i1.15017

This is an open access article under the CC-BY-SA license.

\section{INTRODUCTION}

Every teaching and learning process requires instructional materials. Undeniably, they play important roles in the process (Dewi \& Primayana, 2019; Dudley-Evans, St John, \& Saint John, 1998, p. 170). They become guidance for teachers and students to accomplish the classroom activities. Without any learning materials, the students are unable to achieve the learning objectives properly. Considering its importance, it is strongly advisable for every school to provide the students with subjects that use sufficient materials.

One of the schools that requires the sufficient learning materials is Madrasah Aliyah Al Ma'had An Nur. It is one of private Islamic senior high schools located in Ngrukem, Pendowoharjo, Sewon, Bantul, Daerah Istimewa Yogyakarta. It was founded under the foundation of Pondok Pesantren (traditional Muslim school) Al Ma'had An Nur, Bantul, Yogyakarta.

All students who study at this institute belong to santri (traditional Muslim school students). They stay at pesantren (Islamic boarding school) and live a different daily life from people in common. Their daily activities are scheduled at a particular time. Most of them deal with religious studies, particularly Koranic studies. Considering this life background, it is necessary for particular subject teachers at Madrasah Aliyah Al Ma'had An-Nur to design any learning materials that include any subject matters dealing with it.

One of the subjects in this school that requires a specific learning material developed by including any subject matters relating to the students' life background is Conversation. This subject is given to the tenth to twelfth-graders. Unlike English subject that covers all the four language skills to master, this subject, however, only focuses on speaking skill mastery.

In this institute, this subject needs materials development because there is a problem existing in terms of learning material provision that makes the teaching and learning process go insufficiently. This subject has no specific and 


\section{LingTera,6 (1), 2019 - 42 \\ Mujawazah Mujawazah, Agus Widyantoro}

adequate learning materials during its practice. Based on the observation and interviews with some teachers teaching the subject in this school, it was found that the teachers did not use specific and adequate materials to teach the students during the teaching process in the Conversation class. Up till now, they only adapt the learning materials from an English textbook used by the teacher teaching English subject and do some development when necessary. They take and select materials from the textbook that only focus on speaking skill mastery such as dialogues, English expressions, and the like.

This problem needs a solution. The students should be provided with specific speaking materials that meet their learning needs when attending the Conversation class. Therefore, this research study is conducted to develop appropriate speaking materials for the tenthgraders at Madrasah Aliyah Al Ma'had An-Nur, Bantul, Yogyakarta. The materials hopefully can support the learning process in the Conversation class in the school.

\section{METHOD}

This study is a development research. It employed the combination of Research \& Development model proposed by (Borg \& Gall, 1983) and the linear Model X recommended by Masuhara. The model was modified to make it suitable with the process of developing speaking materials in this research.

The development of the materials was carried out through several steps, namely collecting data and information, a course grid design, product development, product validation, product revisions, try-outs, and final product development. In collecting data and information, it was initially done by conducting a needs analysis. This process was conducted in order to gain information about the students' target needs and learning needs in attending Conversation class. The information was acquired from questionnaires distributed to 30 tenth-graders at Madrasah Aliyah Al Ma'had An Nur, Bantul. The results of the questionnaires were subsequently considered to determine the goals and the learning objectives. Collecting the data was also conducted by interviewing some parties, namely the tenth-graders and teachers, who teach Conversation class, in Madrasah Aliyah Al Ma'had An Nur. The results of the interview were used to strengthen the previous data gained from the questionnaires. Another way to collect data was through observation. In this research, the process was conducted by directly observing the teaching and learning process during the Conversation class at Madrasah Aliyah Al Ma'had An Nur attended by the tenth-graders. The researcher gathered all necessary information from the observation to support and complete the previous data gained from the questionnaires and interviews.

Since more data were needed, the studying of literature became the other source of information needed to collect the data. It was conducted by reviewing some supporting sources such as books, journals, and thesis or dissertations. All information and theories from the sources that enabled to strengthen and support the issue in this research study were included as well.

Next, the second step in developing the product of this research was making goals and learning objectives. The two were determined by considering the result of the needs analysis referring to the students' target needs and learning needs of the data gained previously. The two components were also prominently required to make the learning materials clear about the reason why the learning materials were necessary to be developed.

The third step was to design a syllabus/ course grid. It was designed by considering the goals and learning objectives determined previously. The syllabus/course grid covers descriptions of the content of the learning materials. The descriptions included unit titles, topics, language functions, grammar, vocabulary, values, learning activities and input texts, and achievement indicators.

Having designed the syllabus, the next step was designing the learning materials. The materials focused on speaking skill. Therefore, they included speaking aspects such as vocabulary, pronunciation, grammar and language functions. The materials comprised three units entitled $M y$ Life, My Daily Routines, and My Holiday. Each unit contained topics the most of the students chose when filling in the questionnaires of the needs analysis.

The fifth step to conduct was getting validation from the experts. It was intended to acquire judgments that the materials were appropriate to be delivered to the target learners. The judgments cover two aspects. They refer to the content and the graphic design of the developed materials. Therefore, there were two experts involved in this research. They were a learning materials expert and a graphic designer. 


\section{LingTera,6 (1), 2019 - 43 \\ Mujawazah Mujawazah, Agus Widyantoro}

The sixth step to conduct was revising the materials. Some corrections and evaluation from the experts were considered to make the materials better. The evaluation was necessary to measure whether the materials have been already proper or not to be implemented. Therefore, some revisions were made to the materials after getting feedback from both content and graphic experts. Since the materials will be implemented in the real process, they should contain proper subject matters that can really support the students to require useful knowledge and skill.

The seventh step to conduct was trying out the materials. The try-outs were accomplished in Madrasah Aliyah Al Ma'had An Nur. They took three meetings considering the number of units. Each unit was tried out in one meeting. The tryouts were purposely conducted to gain some information, particularly in line with the appropriateness of the material with the students' needs.

The eighth step to conduct was revising the materials. The materials were once again revised after the try-out. It is necessary to carry it out in order to get some suggestions from the participants. They may find some weaknesses from the learning materials. Therefore, it should be considered as well.

The last step to conduct was writing the final materials. Some additional revisions have been made to the materials. All the recommendations and some corrections were included to complete the final learning materials. Some suggestions both from the experts and the participants were considered as well. Therefore the materials could be implemented appropriately during the teaching and learning process.

In terms of the try-out of the product, it was conducted in two designs: (1) the evaluation from the experts of the materials and graphic design, (2) the evaluation of the students. The materials expert and the graphic designer gave their suggestions and comments about the weaknesses, the lack and the strength of the first draft of the product before the product was tried out in the field. The materials expert focused on the content, language and activities while the graphic design expert focused on the layout and readability of the product.

The second evaluation was from the students. In this research, this involved 30 tenthgraders at Madrasah Aliyah Al Ma'had An Nur, Bantul. The students gave their perception towards the task components of each unit included in the materials developed.
In relation to the instruments and data collection, this research study utilized some instruments and collected two kinds of data; quantitative and qualitative. The quantitative data were collected through questionnaires. The questionnaires employed to obtain the data covered the needs analysis questionnaires, experts' judgment questionnaires, and try-out questionnaires. The researcher also conducted some interviews and observation. The interviews were addressed to several tenth-graders that belong to the subjects of the research. Meanwhile, the researcher conducted the observation by directly visiting the school, in this case, Madrasah Aliyah Al Ma'had An Nur, and observing the teaching and learning process in the Conversation class. Therefore, the researcher can gain more additional information that can support the data gained from the questionnaires. In terms of analysis, the data were analyzed both quantitatively and qualitatively. The results of the questionnaires were analyzed quantitatively by utilizing descriptive statistics while some data gained from the results of the interviews and observation were analyzed qualitatively.

Next, data related to the evaluation from experts and feedback from the students were collected and described by considering a 4 to 1 Likert scale. The respondents should tick $(\sqrt{ })$ one of the four scales. Each scale represents their acceptance with ranges from a very positive to a very negative response: 4 for 'strongly agree', 3 for 'agree', 2 for 'disagree', and 1 for 'strongly disagree'.

Meanwhile, in classifying the category of the mean scores, a quantitative data conversion proposed by (Suharto, 2006, pp. 52-53) was employed. Based on the calculation, the class interval was presented in Table 1.

Table 1. Scoring of Questionnaire Form

\begin{tabular}{cll}
\hline Scale & Category & \multicolumn{1}{c}{ Interval scores } \\
\hline 1 & Poor & $1 \leq \mathrm{X} \leq 1.74$ \\
2 & Fair & $1.75 \leq \mathrm{X} \leq 2.49$ \\
3 & Good & $2.50 \leq \mathrm{X} \leq 3.24$ \\
4 & Very Good & $3.25 \leq \mathrm{X} \leq 4$ \\
\hline
\end{tabular}

The minimum acceptance in this research study was 2.5 . It means that the results of the implementation of the learning materials designed are appropriate to apply if the main scores obtained were equal to or more than 2.5. In conclusion, the materials are sufficient to be applied in the Conversation class if the judgments, evaluation, comments, and suggestions 


\section{LingTera,6 (1), 2019 - 44 \\ Mujawazah Mujawazah, Agus Widyantoro}

from the experts and the students point to at least a score of 'good' to the developed materials.

\section{RESULTS AND DISCUSSION}

\section{The Results of Planning}

At the needs analysis conducted at Madrasah Aliyah Al Ma'had An Nur, Bantul, there were some data obtained. 97 percent of the 30 students involved stated that their objective in attending Conversation class was to be able to speak and communicate in English properly. 87 percent of 30 the students wanted to master the expression of introducing others. 93 percent of the 30 students preferred daily routines in pesantren (Islamic boarding school) as topics to be discussed during the Conversation class. 90 percent of the 30 students found it difficult to pronounce English vocabulary accurately. 83 percent of the 30 students expected audio-visual inputs such as music videos, movies, and English dialogues videos to support their learning process. 73 percent of the 30 students liked to practice their speaking skill through dialogues. In the further interview, there was additional information gained. The students said that it would be more interesting if they could discuss subject matters dealing with their daily life in pesantren when practicing English in the Conversation class. They also added that the types of activities conducted in the class should vary so that they would not get bored.

\section{The Results of Developing the Materials}

The first activity conducted in developing the learning materials was designing a course grid. It was purposely designed for three units and intended for one semester. It comprised unit titles, topics, language functions, grammar, vocabulary, values, learning activities and input texts, and achievement indicators.

Having designed the course grid, the next activity was to develop the first draft of the learning materials. There were three units included in the first draft of the learning materials in this research. Each unit has a title. The three titles were My Life, My Daily Routines, and My Holiday. These titles were created by considering the topics the students mostly chose according to the results of the needs analysis.

Each unit included several tasks which were designed only to support the learners' speaking skill. The organization of all units consisted of three parts, namely the introductory part, the main learning part, and the enrichment part. The introductory part presented a unit title, a sub-title, and a list of learning objectives.

The main learning part covered two sections, namely a warming-up activity and a main learning activity. The warming-up activity consisted of tasks purposely designed to arouse students' curiosity and elicit their background knowledge of the materials to be learned in the unit. Meanwhile, the main learning activity included several tasks designed to guide the students to improve their language skills, particularly the speaking skill.

Next, the enrichment part included glossaries that were purposely arranged to augment the students' repertoire of English vocabulary. This part was optimally developed considering the result of students' needs pointing out that most of the students reside in the elementary proficiency level representing their ability to communicate with limited English vocabulary. It also significantly plays an important role in each unit considering that vocabulary is a 'basis for communication' as strengthened by (Dakhi \& Fitria, 2019, p. 23).

Unit 1 has a title, namely My Life and presents a subtitle Talking About Me. It consists of 14 tasks that are purposely designed to improve students' speaking ability to give detailed information of both one's and others' identity. It includes two types of language expressions. They are expressions of introducing oneself and others.

Task 1 is a guided task. It includes an activity where the students are guided to watch a video that can stimulate their curiosity about the topic being discussed. Based on the video, the students are asked to answer several questions. This task is intended as a warmer for the students. It aims to open the students' mind of the language type being discussed.

Task 2 presents an activity where the students have to study some expressions of introducing oneself. It is also the continuance of the first task. In Task 1 the students have already learnt how the expressions were applied through a dialogue as seen in the video. In Task 2, the students then learn about the expressions theoretically. To reinforce their comprehension toward the language type, this task also provides an exercise where they have to complete a short paragraph with the expressions of introducing oneself.

Task 3 is a semi-guided task. It includes an activity where the students are asked to study illustrations and then complete a dialogue based on the illustrations. This task is purposely 


\section{LingTera,6 (1), 2019 - 45 \\ Mujawazah Mujawazah, Agus Widyantoro}

designed to test and find out how well the students understand a discourse, particularly dealing with the application of expressions of introducing oneself in a dialogue.

Task 4 is also a semi-guided task. In this task, the students are asked to interview their peers based on several questions as the guidance. The questions closely deal with students' self identities. This task is created to foster students' skill in practicing English.

Task 5 presents a list of vocabulary including its pronunciation. In this task, the teacher practices how to pronounce the vocabulary and then the students imitate him or her. (Al-Tamimi \& Attamimi, 2018, p. 72) concluded this method as a sufficient and potential method for fostering students' speaking skills.

Task 6 is a semi-guided task. It includes an activity where the students are instructed to match an English vocabulary with its Indonesian translation. The goal of this task was to reinforce the students' repertoire.

Task 7 includes an activity where the students are asked to read a dialogue and then practice it with their partners in front of the class. Before practicing the dialogue, the teacher as the facilitator exemplifies how to pronounce it and then the students repeat it. This task is purposely designed to guide students to practice their speaking skill through a dialogue.

Task 8 is a free guided task. It includes an activity where the students are asked to create a short conversation based on providing illustrations. It is purposely designed to foster students' ability in applying expressions of introducing oneself through a dialogue.

Task 9 presents a warmer for the students. In this task, they are asked to answer some questions based on a provided illustration. This task is designed to bring students' focus into another language type, namely the expression of introducing others. Including an input in the form of a picture in this task is purposely to grasp students' interest in order to pay more attention to the topic being discussed.

Task 10 presents an activity where the students are asked to learn some expressions of introducing others. It is purposely designed to give students more information about this language type. To reinforce the students' comprehension toward the language type, this task also provides an exercise where the students have to complete a short paragraph with the expressions of introducing others.
Task 11 is a guided task. In this task, the students are asked to study an illustration and then complete a dialogue based on the illustration. It includes an activity that has a goal to test and find out the students' comprehension of the expressions of introducing others applied in a dialogue.

Task 12 is also a guided task. This task includes an activity where the students are asked to introduce one of their classmates in front of the class. The exercise requires students to apply the expressions of introducing others into a practice. This activity aims to foster students' speaking skill, particularly in line with the use of the language type being discussed in a spoken discourse.

Next, Task 13 includes some English dialogues requiring students to complete them with their own utterances including the expressions of introducing others and also by considering some provided illustrations. The illustrations are in the form of pictures of some people along with their own personal identities. This activity aims to foster students' ability in applying the language type being discussed in a dialogue.

Task 14 is a free guided task. It includes an activity where the students are instructed to create a short English dialogue based on providing illustrations. It is purposely designed to foster students' ability in applying expressions of introducing others in a spoken discourse.

The title of Unit 2 is My Daily Routines and presents a subtitle What Does A Santri Do Everyday? It consists of twelve tasks that are provided to improve students' speaking ability to give detailed information of daily routines by including the expressions of giving compliments and showing attention.

Task 1 is a guided task. It includes an activity where the students are instructed to look at some pictures of daily routines of students at a traditional Muslim school. This task is intended as a warmer. It is purposely designed to stimulate students' curiosity about the topic being discussed. Based on the pictures, the students are subsequently asked to answer several questions. It aims to open the students' mind of the language function being discussed referring to the expressions of giving compliments.

Task 2 is a guided task. It presents an activity where the students have to study some expressions of giving a compliment followed by their responses. It is also the continuance of the first task. In Task 1, the students have already been encouraged to use expressions of giving 


\section{LingTera,6 (1), 2019 - 46 \\ Mujawazah Mujawazah, Agus Widyantoro}

compliment based on the pictures. In Task 2, they then learn about the expressions theoretically.

Task 3 presents a list of vocabulary dealing with the students' background and life experience. In this task, they are instructed to pronounce some English vocabulary the teacher has already dictated. This task is really recommended to them since it enables them to foster their pronunciation skill.

Next, Task 4 includes an activity where the students are instructed to match an English vocabulary with its Indonesian translation. This activity is more challenging instead of only searching a definition in a dictionary that sounds more boring. A matching task is regarded sufficient to encourage students to find the definition of the particular vocabulary. The goal of this task is to reinforce the students' repertoire.

Task 5 is a semi-guided task. In this task, the students are asked to complete a dialogue based on an illustration. This task is purposely designed to test and find out how well they understand a discourse, particularly dealing with the application of expressions of introducing oneself in a dialogue.

Task 6 is a free guided task. In this task, the students are instructed to match some vocabulary with their definitions. The vocabulary refer to several Islamic terms the students are familiar with. They deal with their background as santri living in a traditional Muslim school. The goal of this task is to facilitate students to express and explain an Islamic term in English.

Task 7 presents a dialogue. In this task, the students are instructed to practice it with their partners. The dialogue includes all Islamic terms as listed in Task 6. This task is purposely designed to help students to comprehend how the terms are applied in a sentence so that they can practice how to use them in a discourse appropriately. In addition, the dialogue also talks about a daily routine of a santri at a traditional Muslim school. Therefore, it enables students to know how to inform others about their daily routines in their living place in English.

Next, Task 8 is a semi-guided task. In this task, the students are instructed to interview one of the students living at a traditional Muslim school about his or her daily routines. During the interview, they should apply the expression of giving compliments with its response. The goal of this task is to foster students' ability in applying the language function being discussed in a dialogue.
Task 9 is a warmer. It presents an input in the form of a picture. In this task, the students are asked to identify the picture and answer several questions based on the picture. This activity aims to bring students into an introductory topic about a language function, namely the expression of showing attention and its response.

Task 10 provides information about the types of language function being discussed. In this task, the students are instructed to learn some expressions of showing attention with their responses. This task has a goal to guide them to learn more examples about the expressions along with their responses. In addition, it also includes some exercises to test and find out the students' competence in responding to the expression of showing attention in spoken discourses.

Task 11 is a semi-guided task. It includes an activity where the students are asked to continue some dialogues by including the expression of showing attention. Having completed it, they should practice it with their partners in front of the class. The activity was designed with the aim of improving students' speaking skill through practice.

Next, Task 12 is a free guided task. In this task, the students are instructed to create short dialogues based on providing illustrations. Like the previous task, this activity also aims to know how well the students can practice the language function being discussed.

The final task is Task 13. It is also a free guided task. In this task, the students are instructed to create a short dialogue based on a provided illustration in the forms of a picture. Like the previous task, this activity also aims to know how well the students can practice the language function being discussed.

Unit 3 has a title My Holiday and presents a subtitle What Is Your Plan during Your Holiday? It consists of 13 tasks that are provided to improve students' speaking ability in giving detailed information about a plan during their holiday by including the expressions of informing a plan. In addition, this unit also includes another language function referring to the expression of congratulation and its response.

Task 1 is a guided task. It includes a video as a way to support the learning materials to be more interactive and attractive as stated by (Rohmah, 2019, p. 63). Based on the video, they are asked to answer several questions. This activity is purposely designed for the students to encourage them to elicit information on the topic being discussed. This task is intended as a 


\section{LingTera,6 (1), 2019 - 47 \\ Mujawazah Mujawazah, Agus Widyantoro}

warmer aiming to open the students' mind of the language function being discussed referring to the expression of informing a plan.

Task 2 presents an activity where the students are instructed to learn the expressions of informing a plan theoretically. This part includes a table explaining the pattern. To reinforce the students' comprehension toward this language function, this task also provides an exercise where the students should complete some short dialogues with the expression of informing a plan.

Task 3 presents a list of vocabulary dealing with students' experience. In this task, they are instructed to repeat what the teacher has already dictated. It aims to improve students' skill in pronouncing English vocabulary.

Task 4 is a semi-guided task. It includes an activity where the students are instructed to match an English vocabulary with its Indonesian translation. The goal of this task was to reinforce the students' repertoire.

Task 5 is a guided task. It includes an activity where the students are asked to listen to the teacher reading a dialogue. Having listened, the students are subsequently asked to practice the dialogue with their partners. This task is purposely designed to encourage students to practice their speaking skill. In addition, the dialogue includes some vocabulary relevant to their background as santri living at a traditional Muslim school. Therefore, it enables them to know how to apply the vocabulary in a sentence properly.

Task 6 is a semi-guided task. In this task, the students are asked to make a short dialogue based on providing pictures and illustrations. This task includes some pictures relating to the holiday. The goal of this task is to improve students' ability in using an expression of informing a plan to others in a spoken discourse.

Task 7 is a free guided task. It includes an activity where the students are asked to work in pairs to create a script of a short play based on a provided picture. The picture portrays a student interviewing a tourist who is having a holiday in Yogyakarta. This task is purposely designed to foster students' ability in applying expressions of informing a plan through a dialogue.

Task 8 is a guided task. It presents a warmer for the students. In this task, they are asked to look at a picture of a family performing Hajj. They are subsequently instructed to answer some questions based on the picture. Including an input in the form of a picture is purposely to grasp students' interest in order to pay more attention to the topic being discussed. This task is also designed to bring students' focus into an introduction of another language type, namely the expression of congratulation.

Task 9 is a guided task. It presents an activity where the students are asked to learn some expressions of congratulation. It is purposely designed to give students more information about this language function.

Task 10 is a semi-guided task. In this task, the students are asked to continue some dialogues, including the expressions of congratulation by using their own sentences. The goal of this task is to test how well the students can produce sentences and apply the language function being discussed in a spoken discourse.

Task 11 is a free-guided task. It includes an activity where the students are asked to create short dialogues based on providing illustrations. This activity aims to foster students' speaking skill, particularly in line with the use of the language type being discussed in a spoken discourse.

Task 12 is also a free-guided task. In this task, the students are instructed to create a short dialogue based on a provided illustration in the form of a picture. Like the previous task, this activity also aims to know how well the students can practice the language function being discussed.

The final task is Task 13. It is an enrichment task in the form of a game namely Whispering game. It is included in order to entertain the students and keep them away from boredom.

\section{The Results of Evaluating the Materials}

The learning materials were assessed in order to know the validity and the level of quality. There were two activities conducted: expert validation and students' try-out. Both were presented as follows.

\section{The Expert Validation}

The first drafts of the materials were validated by two experts before they were tried out. The two experts were a materials expert who assessed the contents, activities, and the language, and a graphic designer who assessed the layout and the readability. The details of the validation results can be seen in the Table 2 .

Based on the Table 2, the score of the materials ranged from 3.25 to 3.8 on the scale 1 to 4 . The average score was 3.59 and categorized 


\section{LingTera,6 (1), 2019 - 48 \\ Mujawazah Mujawazah, Agus Widyantoro}

as "Very Good". Thus, the materials were appropriate to be tried-out to the participants.

Table 2. Validation results

\begin{tabular}{cccc}
\hline Aspects & Score & Average & Category \\
\hline Contents & 3.7 & 3.59 & Very Good \\
Activities & 3.25 & & \\
Language & 3.8 & & \\
Graphic & 3.62 & & \\
\hline
\end{tabular}

\section{The Results of the Students' Try-outs}

The first try-out was conducted on September 18, 2016. It was to evaluate the tasks in Unit 1. It involved 30 tenth-graders at Madrasah Aliyah Al Ma'had An Nur as participants. The details of the try-out results can be seen in Table 3 .

Table 3. Evaluation of Tasks in Unit 1

\begin{tabular}{cccc}
\hline Task & Score & Average & Category \\
\hline 1 & 3.36 & 3.3 & Very good \\
2 & 3.38 & & \\
3 & 3.38 & & \\
4 & 3.46 & & \\
5 & 3.42 & & \\
6 & 3.48 & & \\
7 & 2.99 & & \\
8 & 3.41 & & \\
9 & 3.20 & & \\
10 & 3.22 & & \\
11 & 3.21 & & \\
12 & 3.29 & & \\
13 & 3.18 & & \\
14 & 3.22 & & \\
\hline
\end{tabular}

The mean scores of the tasks in Unit 1 ranged from 2.99 to 3.48 . The total average was 3.3 and exceeded the minimum acceptance. It implied that all tasks in Unit 1 were sufficient for the students.

Table 4. Evaluation of Tasks in Unit 2

\begin{tabular}{cccc}
\hline Task & Score & Average & Category \\
\hline 1 & 3.51 & 3.33 & Very good \\
2 & 3.25 & & \\
3 & 3.28 & & \\
4 & 3.38 & & \\
5 & 3.32 & & \\
6 & 3.32 & & \\
7 & 3.4 & & \\
8 & 3.27 & & \\
9 & 3.35 & & \\
10 & 3.4 & & \\
11 & 3.27 & & \\
12 & 3.27 & & \\
13 & 3.32 & & \\
\hline
\end{tabular}

The second try-out was held on September 19, 2016. It was to evaluate the tasks in Unit 2 and also involved 30 students as participants. The details of the try-out results can be seen in Table 4.

The mean scores ranged from 3.25 to 3.51 . The average was 3.33 and exceeded the minimum acceptance. It indicated that all the tasks in Unit 2 were sufficient for the students.

Lastly, the third try-out was conducted to evaluate the tasks in Unit 3. It was held on September 20, 2016. It also involved 30 students as participants. The details of the try-out results can be seen in Table 5 .

Table 5. Evaluation of Tasks in Unit 3

\begin{tabular}{cccc}
\hline Task & Score & Average & Category \\
\hline 1 & 3.39 & 3.34 & Very Good \\
2 & 3.25 & & \\
3 & 3.39 & & \\
4 & 3.38 & & \\
5 & 3.4 & & \\
6 & 3.4 & & \\
7 & 3.4 & & \\
8 & 3.32 & & \\
9 & 3.26 & & \\
10 & 3.24 & & \\
11 & 3.33 & & \\
12 & 3.36 & & \\
13 & 3.32 & & \\
\hline
\end{tabular}

The score ranged from 3.24 to 3.4 . The total average was 3.34 and exceeded the minimum acceptance. Therefore, it can be concluded that all the tasks in Unit 3 were also sufficient for the students.

\section{Discussion of the Final Product}

The final speaking materials developed in this research were presented as follows. They comprised three units consisting 14, 13, and 13 tasks consecutively. In terms of goals, the materials provided students with various conversational contexts dealing with their life background as santri (traditional Muslim school students) by using expressions such as introducing oneself, introducing others, giving compliment and its response, showing attention and its response, informing a plan, expressing congratulation and its response.

In terms of inputs, the materials include instructions, dialogues, texts, pictures, and videos the students regard as comprehensible. (Gogoi, 2015 , p. 20270) stresses that various materials, including such inputs will make the students feel comfortable to move to the next activity. Therefore, it is necessary to include comprehensible 


\section{LingTera,6 (1), 2019 - 49 \\ Mujawazah Mujawazah, Agus Widyantoro}

inputs in learning materials in order to enable students to learn the target language easier.

The materials also include themes and topics that closely deal with the students' life background as santri, for instance, their daily routines in pesantren since they regard them interesting and familiar to them. (Al Azri \& AlRashdi, 2014, p. 251) point that when teaching materials are not interesting and motivating, it will be useless. It is necessary to include themes or topics in any learning materials that are interesting and familiar to the students because they can motivate the students to learn the target language. It is supported by (Walker, 2012, p. 334) who argues that one of features that can make the lesson fun is an interesting topic. It signifies that teachers should select topics for students carefully and make sure that their students are familiar with them and also find it interesting and pleasant as strengthened by (Derakhshan, Khalili, \& Beheshti, 2016, p. 184).

In relation to a procedure, the materials include tasks that are put in a similar order for all units. The tasks are arranged sequentially from warming up activities, main teaching and learning activities, enrichment activities, and to summary activities. The activities begin with identifying input data i.e watching videos and pictures, pronunciations practices, vocabulary mastery, and then end with several dialogue practices. The materials contain more dialogues practices considering the students' preference to have more those activities than any others. This is also in line with the finding of (Ampa, Rasyid, Rahman, Haryanto, \& Basri D, 2013, p. 177) showing that most of the students prefer dialogue practices to be included in their speaking materials. The tasks are also arranged sequentially from the easiest to the most difficult ones. It is considered as an effective way to motivate the students to learn the target language. In addition, according (Bhatt, 2012, p. 363) finding, it is found that activities or tasks provided with learning materials belong to communicative tools that can bring 'excellent result'.

In terms of role, the developed materials provide the students with tasks that enable them to participate in the learning process actively. The materials also include tasks that require the teachers to be good facilitators during the instructional process as (Rahimi, 2008, p. 11) reviews that teaching materials should also consider 'an active role' for the teachers. Finally, in terms of setting, the materials include tasks that are mostly accomplished in pairs considering the result of the try-out showing that most of the tasks are considered effective to be accomplished in pairs.

\section{CONCLUSIONS}

Considering the students' target and learning needs, the speaking materials for Conversation class of the tenth- graders at Madrasah Aliyah Al Ma'had An-Nur are explained as follows. The materials are in the form of printed books consisting three units. Each unit consists of 14,13 , and 13 tasks consecutively. In relation to the speaking aspects, each unit mostly includes tasks involving the students in dialogue practices. The materials also provide lists of vocabulary together with their pronunciations. In terms of input, they present texts and audio visual inputs such as videos to encourage the students to learn the topics being discussed. The preferred topics are those dealing closely with the students' daily routines as santri (traditional Muslim students). Meanwhile, the teacher plays role as a facilitator and the students prefer to accomplish most of the tasks in pairs. According to the materials evaluations by experts and try-outs by students, the materials acquired the average score 3.59 and 3.32 of the scale 1 to 4 . Both are categorized as very good. Therefore, materials are considered appropriate for the students.

\section{REFERENCES}

Al Azri, R. H., \& Al-Rashdi, M. H. (2014). The effect of using authentic materials in teaching. International Journal of Scientific \& Technology Research, 3(10), 249-254. Retrieved from http://www.ijstr.org/paperreferences.php?ref=IJSTR-1014-10244

Al-Tamimi, N. O. M., \& Attamimi, R. A. (2018). Using explicit pronunciation instructions to develop students'english speaking competencies: A quasi-experimental study. International Journal of English Language Teaching, 6(4), 57-73. Retrieved from https://www.eajournals.org/journals/intern ational-journal-of-english-languageteaching-ijelt/vol-6-issue-4-may2018/using-explicit-pronunciationinstructions-to-develop-students-englishspeaking-competencies-a-quasiexperimental-study/

Ampa, A. T., Rasyid, M. A., Rahman, A., Haryanto, H., \& Basri D, M. (2013). The students' needs in developing learning materials for speaking skills in Indonesia. 


\section{LingTera, 6 (1), 2019 - 50}

\section{Mujawazah Mujawazah, Agus Widyantoro}

Journal of Education and Practice, 4(17), 171-178.

Retrieved from https://www.iiste.org/Journals/index.php/J $\mathrm{EP} /$ article/view/7404

Bhatt, S. K. (2012). Using self-study material for classroom teaching. Electronic Journal of Foreign Language Teaching, 9(1), 347365. Retrieved from http://eflt.nus.edu.sg/v9s12012/bhatt.pdf

Borg, W. R., \& Gall, M. D. (1983). Educational research: An introduction. New York: Longman.

Dakhi, S., \& Fitria, T. N. (2019). The principles and the teaching of English vocabulary: A review. JET (Journal of English Teaching), $5(1)$, https://doi.org/10.33541/jet.v5i1.956

Derakhshan, A., Khalili, A. N., \& Beheshti, F. (2016). Developing EFL learner's speaking ability, accuracy and fluency. English Language and Literature Studies, 6(2), 177. https://doi.org/10.5539/ells.v6n2p177

Dewi, P. Y. A., \& Primayana, K. H. (2019). Effect of learning module with setting contextual teaching and learning to increase the understanding of concepts. International Journal of Education and Learning, $\quad 1(1), \quad 19-26$. https://doi.org/10.31763/ijele.v1i1.26
Dudley-Evans, T., St John, M. J., \& Saint John, M. J. (1998). Developments in English for specific purposes: A multi-disciplinary approach. Cambridge University Press.

Gogoi, S. (2015). Importance's of teaching learning materials for young Children. International Journal of Current Research, 7(9), 20269-20273. Retrieved from https://www.journalcra.com/article/importa nce $\%$ E2\%80\%99s-teaching-learningmaterials-young-children

Rahimi, D. M. (2008). What do we want teaching-materials for in EFL teacher training programs. Asian EFL Journal, 31, $1-35$.

Rohmah, F. N. (2019). Developing computerbased instructional media for English speaking skill at senior high school. JET (Journal of English Teaching), 5(1), 63. https://doi.org/10.33541/jet.v5i1.960

Suharto, G. (2006). Pengukuran dan hasil penilaian hasil belajar Bahasa Inggris. Yogyakarta: Fakultas Bahasa dan Seni, Universitas Negeri Yogyakarta.

Walker, I. (2012). Instructional materials for developing multi-competencies: The case of performative exercises. Electronic Journal of Foreign Language Teaching, 9(SUPPL.1), 325-346. 